\title{
Public Debt and Budget Deficit: Gauging the Impact on Malaysia's Economic Performance
}

\section{Zuriyati Ahmad, Ahmad Syakir Ammar Ahmad O'llia, Rosman Mahmood}

To Link this Article: http://dx.doi.org/10.6007/IJARBSS/v11-i18/11433

DOI:10.6007/IJARBSS/v11-i18/11433

Received: 22 August 2021, Revised: 25 September 2021, Accepted: 08 October 2021

Published Online: 26 October 2021

In-Text Citation: (Ahmad et al., 2021)

To Cite this Article: Ahmad, Z., O'llia, A. S. A. A., \& Mahmood, R. (2021). Public Debt and Budget Deficit: Gauging the Impact on Malaysia's Economic Performance. International Journal of Academic Research in Business and Social Sciences, 11(18), 151-159.

Copyright: (C) 2021 The Author(s)

Published by Human Resource Management Academic Research Society (www.hrmars.com)

This article is published under the Creative Commons Attribution (CC BY 4.0) license. Anyone may reproduce, distribute, translate and create derivative works of this article (for both commercial and non-commercial purposes), subject to full attribution to the original publication and authors. The full terms of this license may be seen

at: http://creativecommons.org/licences/by/4.0/legalcode

Special Issue Title: TiBECVII 2021, 2021, Pg. 151 - 159

Full Terms \& Conditions of access and use can be found at http://hrmars.com/index.php/pages/detail/publication-ethics 


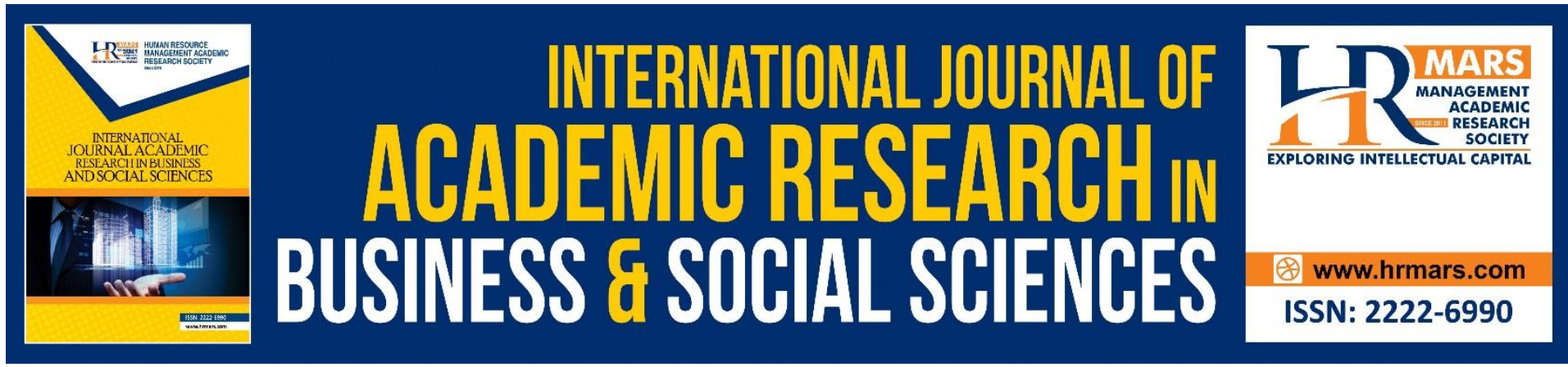

\title{
Public Debt and Budget Deficit: Gauging the Impact on Malaysia's Economic Performance
}

\section{Zuriyati Ahmad, Ahmad Syakir Ammar Ahmad O'llia, Rosman Mahmood}

Faculty of Business and Management, Universiti Teknologi MARA Cawangan Terengganu, Malaysia

Email: zuriy271@uitm.edu.my

\begin{abstract}
Malaysia has been experiencing large budget deficits financed by increasing debts throughout the years especially after the Asian Financial Crisis. Many studies have highlighted that the persistent increases in the budget deficit and large debt are the paramount issues that might drag the economy in the country. This study is therefore attempting to gauge the impact of the budget deficit and public debt on Malaysia's economic performance. Johansen cointegration method is utilized in this study as longer period of observation is used. The quarterly data spanning from 1998 to 2016 is tested using this method. Finding reveals that budget deficit has negative impact on the economic performance however it has insignificant influence in the long run equilibrium. While the public debt is divided into two components namely domestic debt and external debt. Both debts are found to have positive and significant impact on economic performance in the long run equilibrium approach. This implies that against previous researches, public debt either domestic or external debt can spur the economic performance for the country through the expenditure that lead to the economic development in the long run equilibrium.
\end{abstract}

Keywords: Public Debt, Budget Deficit, Economic Performance, Cointegration

\section{Introduction}

In most of the countries in the world there are two paramount macroeconomic issues that have been highlighted; the persistent of budget deficit and the government debt. Budget deficit and public debt and are interrelated as they affect each other. The persistent of budget deficit will lead to the instability to any countries. Theory suggests that persistent and large deficits lead to a harmful effect on major macroeconomic fundamental. Public debt for example plays important role in the economic development process. Nonetheless, its impact on economic growth and performance incessantly leads argument between researchers and policy makers and due to its inconclusive results. The Keynesian model for example argues that no real burden is associated with public debt and that has no significant impact on economic growth (Metwally \& Tamaschke, 1994). While Vo et al (2020) stated that the real burden happens at the time government spending is made when real resources are used up. 
Malaysia has been experiencing large budget deficits financed by increasing debts throughout the years after the Asian Financial Crisis, as a result of expansionary fiscal policies aimed at stimulating growth through increased consumption (Siew \& Yan, 2015). The debate on whether the public debt level of Malaysia is on a sustainable path also comes into question as Malaysia has considerably high debt and fiscal balance ratios. Malaysia has recorded a fiscal deficit position since its independence in 1957 except for the year 1993 and 1997. This has raised the concern of policymakers and academicians alike and created many discussions regarding the budget deficit of the Malaysian economy. The expanding in budget deficit has become a major concern because increasingly more debt is needed to finance the government's budget deficit should it continue to widen (Cheong et. al, 2011). Furthermore, Malaysia has recorded 15 consecutive years of fiscal deficits since the year 1998 for example -RM5 billion in 1998, -RM20.6 billion in 2007 and -RM37.4 billion in 2014. This condition has led Malaysia to accumulate a stock of indebtedness regardless of domestic or international capital markets since, by continuing to run budget deficits, the country would have a high stock of debt (Nurazira, 2016). In addition, the federal government debt was financed from domestic and external sources, which constituted approximately 96.2 per cent and 3.8 per cent of the gross borrowing respectively. As at the end of year 2014, total federal debt was recorded at RM582,828.00 (BNM, 2017). This statistic has already been reached and is slightly higher than the prudent cut-off point of public debt. The importance of analysis on Malaysia should be highlighted before it is too late. Meanwhile, it is also to prevent danger of a government facing more deficits that might turn our economy unstable. Therefore, this study aims to highlight the above issues by gauging the impact of the budget deficit and public debt on Malaysia's economic performance in Malaysia.

The remaining of the paper is organized as follows. Section 2 discusses the literature review. The methodology under consideration will be highlighted in section 3 . Section 4 discusses result and discussion. Lastly, section 5 offers conclusion.

\section{Literature Review}

Public debt generally is defined as a debt that the government owes to economic sectors. In the theoretical literature public debt and economic growth tends to point to a negative relationship. For example, based on the augmented growth model, public agents issuing debt to finance consumption or capital goods. Therefore, in the neoclassical setting, the relationship between public debt and economic growth exhibits more to a negative relationship. While, Modigliani (1961), argued that the national debt is a burden for next generations, which comes in the form of a reduced flow of income from a lower stock of private capital. In more recent researches Ochieng (2013); Coupet (2017) discuss on the theoretical part of government debt. Using the Harrod Domar Growth theory, Ochieng (2013) concluded that domestic debt in Kenya was reasonably sustainable to economic growth. While Coupet (2017) extended the theory of augmented Solow Model and incorporating public debt and nation output. The use of cointegration and error correction model reveal that the public debt in the short run and long run effects are significant towards the economic growth.

The public debt issue has been highlighted by researches such as Md Saifuddin (2016), ljirshar, Joseph and Godoo (2016); Cheong et. al (2011); Lee and Ng (2015); Danial et al. (2017) and Vo et al. (2020). Hassan and Akhter (2012); Saifuddin (2016) both study in the case of 
Bangladesh using the cointegration test. Both studies concluded that the effect of public debt burden on the economic growth. Hassan and Akhter (2012) found that that the domestic debt and external debt have negative relationship with economic growth. Vo et al. (2020) on the other hand using the panel data to study on public debt and budget deficit in developed and developing countries. With the data spanning from 2004 to 2015 and using 59 countries, the finding shows that there is negative relationship between national debt, budget deficit and economic growth. The finding implies the national debt and budget deficit can harm and drag the economy of the countries chosen. Nonetheless, ljirshar et al (2016) examine the relationship between external debt and economic growth of Nigeria for the period of 1981 until 2014. Contrary to other studies it is revealed that external debt has positive relationship with economic growth of Nigeria.

Specifically studying on the issue of budget deficit, Cheong et. al (2011) stated that the expanding in budget deficit has become a major concern it is widen and it can harm the government. While Nurazira (2016) states that the accumulation of stock of indebtedness regardless of domestic or international capital markets by continuing to run budget deficits will led the country to have a high stock of debt. In Pakistan, Fatima (2012) investigating the impact of budget deficit on economic growth. Utilizing the time series data from the period of 1978 to 2009 and employed the multivariate equation the study found that the budget deficit has negative relationship on economic growth of Pakistan during the sample period. This in contrary with Fatima (2011), the positive relationship is found between budget deficit on the economic performance. In support to Fatimah (2011); Najid (2013), confirmed that the budget deficit has a positive relationship on the economic growth of Pakistan and there was bi-directional causality relationship between the variables. While, Edame and Okoi (2015) use the Chow endogenous break test, Co-integration test to study in the case of Nigeria. This study also found that the budget deficit is significantly and positively impacted on economic growth.

Hayati (2012); Siew and Yan (2015); Danial et al (2017) among the studies which have been done in the case of Malaysia. Hayati (2012) for example used quarterly data from 2000 until 2011with ARDL approach to determine the long-run relationship between all series since it can cater for small sample size. The result reveals that there is no long-run relationship between government's debt and economic growth. However, productive expenditure has positive long-run relationship with the economic growth. Hayati (2012) suggests if there is a shock in the Malaysian economy, the only variables that can help to converge the economy to its equilibrium is the changes in GDP and productive expenditures. While Siew and Yan (2015) estimate the public debt contribution to the economic growth in Malaysia over the period of 1991 to 2013 . The result shows there is a consistent finding with previous literature which it has a negative impact on GDP. It is also found that the budget deficit will decrease the function of GDP. Muhammad Danial et al (2017) highlighted there is a persistent increase in the government debt in Malaysia and raised a concern. Using a similar method of ARDL, the findings indicate differently from previous study which shows the government debt is an important macroeconomic element to sustainable growth of Malaysia.

\section{Methodology}

This study tries to divert from other previous studies in Malaysia as it utilized different empirical method. Most of the studies in Malaysia (Hayati, 2012; Siew \& Yan, 2015; Danial et al., 2017) utilized ARDL method as they have short period of time under observation. Whilst 
this study utilized the Johansen cointegration method as it uses longer period of observation. Quarterly data set of 19 years covering from 1998 to 2016 is used in this study. The observation is adequate for the method chosen. Sample is restricted to this time span in order to get uniformness of the data set and considering the availability of the data. Data is obtained from Bank Negara Malaysia Statistical bulletin. Another diversion of this study from previous studies is that the public debt is divided into two categories which are domestic and external debt. The estimated linear regression of the model is therefore as follows;

$E P=\alpha-\beta_{1} D O M D-\beta_{2} E X T D-\beta_{3} B D+\varepsilon$

Based on the model, EP indicates economic performance which is been measured by GDP. DOMD and EXTD represent the public debt which the domestic debt and external debt. BD shows the budget deficit. While $\alpha$ and $\beta$ indicate the constant and coefficient. $\varepsilon$ shows the error term. The expected coefficients are DOMD $<0$, EXTD $<0$ and $B D<0$.

Since the study applies the cointegration method it is therefore important to confirm stationary or non stationary properties of variables chosen. The test for the presence of the unit root test is necessary. The ADF unit root test is based on the null hypothesis $\mathrm{H}_{0}$ : each variable chosen is not I(0). If the calculated ADF statistics is less than the critical value the null hypothesis is rejected, otherwise accepted.

The ADF unit root test can be performed by estimating the regression;

$\mathrm{Y}_{\mathrm{t}}=\rho \mathrm{y}_{\mathrm{t}-1}+\alpha_{1} \Delta \mathrm{y}_{\mathrm{t} 1}+\ldots .+\alpha_{\rho-1} \Delta \mathrm{y}_{\mathrm{t}-\rho+1}+\varepsilon_{\mathrm{t}}$

Cointegration analysis will be used by taking the Johansen cointegration test. Cointegration aims at explicitly dealing with the relationship between non stationary time series and spurious result can be avoided. The cointegration test will be based on two tests; trace test statistics and the maximum eigenvalue test statistics. In order to check for the long run equilibrium exists between the variables to achieve the objective, Johansen cointegration test (Johansen, 1988 and Johansen and Juselius, 1990) is used.

\section{Results Analysis and Discussion}

As stated earlier in order to test using the cointegration method it is necessary to conduct Augmented Dickey-Fuller (ADF) test in order to check whether the series of the data is stationary or non-stationary. Table 1 provides the summary of stationary test based on Augmentad Dickey Fuller (ADF). Using 1\% significance level, all variables fail to reject the null hypothesis of non stationary at the level form. All variables are found to be stationary at their first difference form. Therefore, the null hypothesis of non stationary can be rejected. All variables are I(1) or integrated of order 1 . The result is fulfilling the requirement to proceed for the next step. 
Table 1: Stationary Test

\begin{tabular}{llll}
\hline Variable & Level I(0) & First differences I(1) & ADF Value \\
\hline EP & 2.0030 & $5.4284^{* * *}$ & 3.5270 \\
DOMD & 0.4333 & $8.8386^{* * *}$ & 3.5203 \\
EXTD & 0.3767 & $8.2154^{* * *}$ & 3.5203 \\
BD & 2.4649 & $17.1874 * * *$ & 3.5242 \\
\hline
\end{tabular}

As the order of integration is established for each variable, this study continues to evaluate the cointegration test for the data series. The cointegration test is used to determine whether a linear combination of the series has a long run equilibrium.

Table 2: Johansen Cointegation Test Result Unrestricted Cointegration Max Eigenvalue and Rank Test (Trace)

\begin{tabular}{lllll}
\hline $\begin{array}{l}\text { Hypothesized } \\
\text { No. of CE(s) }\end{array}$ & $\begin{array}{l}\text { Max } \\
\text { Eigenvalue } \\
\text { Statistics }\end{array}$ & $\begin{array}{l}\mathbf{0 . 0 5} \\
\text { Critical } \\
\text { value }\end{array}$ & $\begin{array}{l}\text { Trace } \\
\text { statistics }\end{array}$ & $\begin{array}{l}\mathbf{0 . 0 5} \\
\text { Critical Value }\end{array}$ \\
\hline None * & 44.9859 & 27.5843 & 69.2262 & 47.8561 \\
At most 1 & 14.4917 & 21.1316 & 24.2403 & 29.7971 \\
At most 2 & 9.5838 & 14.2646 & 9.7486 & 15.4947 \\
At most 3 & 0.1648 & 3.8417 & 0.1648 & 3.8415 \\
\hline
\end{tabular}

Result from the Johansen cointegration test is demonstrated in Table 2. From the analysis of the maximum eigenvalue, the model shows the presence of one cointegrating equation since these statistics exceed their critical value at the $5 \%$ significance level. Since there is one cointegrating relationship between independent variable, the null hypothesis of no cointegration can be rejected.

Based on the Johansen co-integration test, the trace test (69.2262) are higher than the critical value (47.8561) whereas the max-eigen value (44.9859) is also higher than the critical value (27.5843). Since the trace test and max-eigen is higher than critical value it shows there is a long run equilibrium. The test suggests that null hypothesis is rejected at the $5 \%$ significance level, which means there is at least one co-integration equation. The result of both tests is essential to be used (Luintel and Khan, 1999). The existence of cointegration implies variables are cointegrated and there is a meaningful long run relationship. Testing with provision of four lags, the model exhibits no diagnostic problems such as serial correlation and normality problem. Therefore, the study has proceeded to the next step to find out the magnitude of the long run relationship. Estimated long run equilibrium model is as follows;

$E P=0.6868 D O M D+0.1856 E X T D-1.3849 B D$
$(17.1743)^{* * *}$
$(3.8252) * * *$
(1.1897)

Notes: In the parentheses are $t$ statistics, $* * * 1 \%$ level of significance

The result in the long-run equilibrium is also showed the domestic debt is positively and significantly and given impact to the economic performance. The higher the domestic debt implies the increase in economic performance. This is due to the funds are used in development of infrastructures. The domestic debt impact towards economic performance when government provides various of infrastructures in a country, it will help towards the 
development of economic because this will encourage investors either locally or foreign investors to invest in Malaysia and therefore increasing the Malaysian economic performance.

Turning to the coefficient of external debt demonstrates a positive relationship and significant at $1 \%$ significance level with economic performance. This higher economic performance will increase happen if the external debt increases. It indicates the magnitude is parallel with ljirshar et al (2016). Nonetheless, it is contrary with the negative result is expected for EXTD based on studies done by Ochieng (2013); Hassan and Akhter (2012). EXTD has positive relationship with economic performance when the money borrowed is effectively managed. During the period of the study, the federal government is laydown guidelines in terms of defining the purpose, duration, moratorium requirements and commitments, negotiation among others including conditions for external debt loans. This will guide against high external debt stock that would lead to exceeding healthy threshold.

Budget deficit is another variable that had been focused in this study. It is expected to be negative magnitude in the estimated model. In parallel with the theory, the relationship of budget deficit and economic performance in the long run equilibrium the magnitude shows a negative sign. Based on the magnitude the finding can be indicated that when government is facing high deficits it might turn our economy unstable. Nonetheless, this cannot be claimed as it is found that budget deficit has insignificant relationship with economic performance in long run equilibrium. In other words, the finding depicts no empirical evidence found that budget deficit will significantly affect the Malaysian economy.

Overall, the analysis can be concluded that domestic debt and external debt have positive significant relationship in the long run equilibrium. This implies that the economic performance will increase if the external debt is increase. Previous researches also have shown ambiguous results are found on the public debt in different countries. For example, ljirshar et al (2016); Ochieng (2013); Saifuddin (2016) positive relationship while Hassan and Akhter (2012); Van (2020) have the opposite findings. While in the case of Malaysia most studies have consistent finding of negative relationship (Siew \& Yan, 2015). Whereas, Nur Hayati (2012) reveals that there is no relationship which is contradicted to this finding. Nevertheless, the result from this study is in support with Danial et al (2017) revealing that the public debt is important macroeconomic element to the economic performance of Malaysia. Instead of expecting the higher public debt will drag the economy, it will spur the economic performance of Malaysia. This study also suggests if there is a shock in the Malaysian economy, the variable that can help to converge the economy to its equilibrium is the changes in economic performance is through government debt that been spent productive expenditures.

\section{Conclusions}

This study aims to gauge the impact of the government and budget deficit on Malaysia's economic performance in the long run equilibrium. It is departed from earlier studies that had been done in Malaysia as firstly, it is divided into two types of debt namely domestic and external debt. Secondly this study used the Johansen cointegration test approach instead of using the ARDL approach. The developed framework has been tested using the cointegration approach. The existence of cointegration in this study implies variables are cointegrated and 
there is a meaningful long run relationship. While, the robustness of the result was tested under various aspects. It is found that the budget deficit follows the expected magnitude, nonetheless it does not have any significant influence in the long run equilibrium. Therefore, there is no evidence to conclude budget deficit had any adverse impact on economic performance. While far from the earlier expectation, the public debt either domestic or external debts will increase the economic performance when testing using cointegration test. Both debts are also found to have significant impact in the long run equilibrium. This finding implies public debt either domestic and external debt are important macroeconomic element to spur the economic performance in Malaysia.

\section{References}

BNM. (2017) Central Bank of Malaysia Report. Federal Government Finance Malaysia

Cheong, K. W., Eddie, Y. M., Lye, K. H., Tan, K. E., \& Tee, W. S. (2011). Debt, Budget Deficit and Economic Growth of Malaysia. Unpublished Dissertation, Faculty of Business and Finance Department of Economics. Universiti Tunku Abdul Rahman.

Coupet, E. J. (2017). Government Debt and Economic Growth. Journal of Applied Economic and Business Research, 7(3), 172-193

Edame, G. E., \& Okoi, O. B. (2015). Fiscal Deficit and Economic Growth in Nigeria: A Chow Test Approach. International Journal of Economics and Financial Issues, 5(3), 748-752.

Fatima, G. M., Ahmed \& Rehman, W. (2012). Consequential effects of budget deficit on economic growth of Pakistan. International Journal of Business and Social Sciences, 3(7) 203-208.

Hassan, M. H., \& Akhter, T. (2012). Impact of Public Debt Burden on Economic Growth: Evidence from Bangladesh. Journal of Finance and Banking, 10(1), 1-13.

Ijirshar, V. U., Joseph, F., \& Godoo, M. (2016). The Relationship between External Debt and Economic Growth in Nigeria. International Journal of Economics \& Management Sciences, 6, 390- 398.

Luintel, K. B., \& Khan, M. (1999). A Quantitative Reassessment of the Finance Growth Nexus, Evidence from the Multivariate VAR. Journal of Development Economic, 60, 381-405

Metwally, M. M., \& Tamaschke, R. (1994). The Interaction Among Foreign Debt, Capital Flows and Growth: Case Studies. Journal of Policy Modelling, 16(6), 597-608.

Modgliani, F. (1961). Long Run Implications of Alternative Fiscal Policies and the Burden of the National Debt. The Economic Journal, 71(284), 730-755.

Danial, M. A. B., Ruhaini, M., Badariah, S. N., Roshyani, A. (2017). Real Effects of Government Debt on sustainable Economic Growth in Malaysia (2017). Journal of International Studies, 10(3), 161-172

Najid, A. (2013). The role of Budget Deficit in the Economic Growth of Pakistan. Global Journal of Management and Business Research Economics and Commerce,13(5).

Hayati, N. A. R. (2012). How federal government's debt affect the level of economic growth? International Journal of Trade, Economics and Finance, 3(4), 323- 326

Ochieng, O. O. (2013). Relationship between public debt and economic growth in Kenya: 1992-2012. Unpublished MBA Project, University of Nairobi.

Siew, P. L., \& Yan, L. N. (2015). Public Debt and Economic Growth in Malaysia. Asian Economic and Financial Review, 5(1), 119-126.

Nurazira, S. M. D. (2016). The Real Effect of Government Debt: Evidence from the Malaysian Economy. Journal of Economic Cooperation and Development, 37(3), 57-86 
Vo, T. T. V., Nguyen, T. T. H., Phan, G. Q., Le, T. H. A., \& Do, T. L. (2020). The Relationship between Public Debt, Budget Deficit and Sustainable Economic Development in Developing Countries: The Role of Corruption Control. Jurnal Ekonomi \& Studi Pembangunan, 21(1) 84-101 